\title{
TRENDS IN MIDDLE CLASS AS A DRIVER FOR STRATEGIC MARKETING
}

\author{
Tamer Cavusgil ${ }^{*}$, Simone Guercini* *
}

The existence of a strong relation between the emergence of the middle class and the spread of modern mass marketing has long been highlighted (Coleman 1983). The ever-increasing purchasing power of the middle class has stimulated the emergence of a mass-market consumer society (Blumin 1989). Nowadays, understanding the evolution of international strategic marketing in emerging countries calls for studying the middle class there. Formulating 'profiles' to describe the middle class in different geographic contexts in order to make comparisons between them is an important part of this process of market representation for strategic marketing.

The relation between the emergence of a middle class and marketing involves multiple levels and its study is bound to lead to the creation of theory as well as practical applications. Brands aimed mainly at middle-class members, which represents a major objective of modern worldwide retail distribution. But what is 'the middle class'? And what are the best parameters on which to base a definition of middle class? On the one hand, it is a segment of the population that has discretionary income at its disposal. So, it is a consuming class whose spending is not oriented solely to subsistence. Moreover, its emergence is quite closely related to urbanization. However, this is just one component of the phenomenon - the tip of the iceberg. The submerged bulk of the iceberg involves its members' education levels and occupations, and at an even more basic level, their values and expectations.

Observing middle class evolution in both advanced and emerging countries today is a fundamental issue in international strategic marketing. The ongoing mega-trends involving the middle class in traditional industrial power economies, as well as the newly developing ones, mirror the processes of globalization. Such trends present a two-faced 'Janus' aspect, leading, on the one hand, to the creation of a transnational market with converging purchasing power, but on the other, the simultaneous persistence of many cultural differences. By way of example, although the Chinese mid-

\footnotetext{
* Georgia State University, Robinson College of Business, Atlanta.

** Università degli Studi di Firenze, Dipartimento di Scienze per l'Economia e l'Impresa, Firenze.
}

Mercati e Competitività n. 3, 2014 
dle class is, through the globalization process, replicating much of the convergence side, it nevertheless differs in many respects from the American or European middle classes. As mentioned, the characteristics and behaviors of the middle class are related to urbanization processes. In addition, the middle class is responsible for most consumption processes, which lay the grounds for the development of an entrepreneurial class. This is because, on the one hand, entrepreneurship is likely to arise from within the components of this class, while on the other, and more importantly, it is precisely thinking about consumers in, and the real or potential needs, of this class that generates many innovative ideas for the largest markets.

The middle class in the main emerging economies seems to be undergoing a different evolution from those in the older industrialized nations. It is remarkable that in the same years that a major crisis in the middle class was reported in industrialized and advanced economies (Roth 2011; Carmichael 2011), there appeared other, even more conspicuous, news of the rapid emergence of the middle class in the new economies - a fact that has been interpreted as a major factor driving the evolution of global markets (Kharas 2010; Banerijee and Duflo 2008; Hong 2014; Mukherjee and Satija 2012).

In emerging countries, a growing number of households have access to substantial disposable income with which to obtain goods and services and acquire durables (e.g., cars, appliances, better quality homes, private education for children, leisure activities, etc..). As far as defining the 'middle class', it has been estimated that in order to be able to refer to a family as 'middle class', at least $30 \%$ of its total household income should be available for discretionary consumption. There is a sizable number of upwardly-mobile households that aspire to enjoying the comfort, lifestyle, and symbols of global and western brands. Discretionary consumption is only one, particularly apparent, part of the phenomenon. Delving a bit deeper, we find different levels of education, occupation, acquired assets, urban quality, and so forth. And at an even deeper level, there are different values, expectations, and attitudes. This new society is characterized by greater educational and professional achievement, more assets (both real and financial), and differing values, attitudes and expectations, with enormous consequences in terms of their political participation, lifestyle, savings versus spending proclivity, attitudes toward borrowing, work-life balance, definition of success, religion, and individualism. The middle class is correlated with such factors as the rapid spread of ICT and social and mobile technologies, because purchasing the associated devices and services accounts for a major portion of their discretionary income expenditures.

The phenomenon of the emerging middle class thus has 'antecedents' and 'consequences'. But is there a relation of cause and effect between them? Are they always the same in different cultural and historical contexts? According to the prevailing view, middle-class phenomena comprise rising wages, substantial disposable income and discretionary consumption. 
Its antecedents include market liberalization reforms, productivity, political stability, as well as globalization and technological advances. Its consequences consist of business and economic transformation, societal, political, and cultural transformation, including democratic political consciousness, transparency, education, health care, urban design, environmental awareness, income disparity, and so forth. It has been hypothesized that, eventually, it should lead to greater income equality (Gini Index), a more vocal and politically active citizenry, and hopefully more transparent governance. Such a view implies a strong relation between economic growth and the existence of a middle class in both advanced and emerging markets.

Why is it so important to take account of the middle-class phenomenon and its antecedents and consequences? And more basically, are the antecedents and consequences really those indicated above? For example, does market liberalization lead to the growth of the middle class, or could it, to the contrary, cause income polarization and a more inequitable redistribution of riches? To answer these questions, consider the divergent paths that has taken place in recent decades in the main emerging and in older advanced markets. Despite the observed correlations, causality remains to be proved in each case.

The subject of middle class growth is of great interest to international strategic marketing. Already today the attention devoted to the emerging markets is more and more dependent on the development of their middle classes. To understand its features is to understand the role of emerging markets in business marketing strategies in the near future. At this point, a question may arise: is it more challenging to study the middle class than the upper class? The answer to this is probably, yes, it is, simply because of the numbers involved, and the fact that such study calls for a coordinated, standardized approach that requires different skills from those leveraged by suppliers of luxury goods for the elite. However, in the end, the development of the luxury market itself has at times been associated with its 'democratization', that is, its opening up to the purchasing power of the middle classes.

Research on the middle class is necessarily trans-disciplinary. It involves research in sociology, anthropology, as well as education, architecture, urban studies, geography, art, business, film, history, mass media, communications, political science and literature. At the same time, the global middle classes will themselves be more and more trans-cultural. In fact, another aspect related to the role of the middle class is globalization. On the one hand, the middle class may be an influential factor in standardization, as it can access standard global consumption, while on the other, its members may need to undergo a good deal of adaptation, as they currently exhibit considerable cultural differences. The ability to 'listen to' and observe the members of the middle class in other countries is a key element in developing marketing strategies, which involves market representation and the formulation of new proposals, new offerings, as well as possibly new business models.

Clearly, the middle class matters because it is considered an engine of economic growth and stimulates competition and the development of quali- 


\section{T. Cavusgil, S. Guercini}

ty products. Although its emergence has important effects on the evolution of the marketing environment, at the same time, it certainly has major impacts on the entrepreneurial side and overall business environment as well. The emergence of this new middle class in developing countries likely represents a source of great stimulus to new entrepreneurship and higher productivity, but at the same time it should not be forgotten that the entrepreneurial spirit may very well arise in the "bottom of the pyramid" (Prahalad 2011). Is the middle class the source or the tomb of the entrepreneurial spirit? Our hypothesis is that the entrepreneurial role of the middle class depends more and more on their experiences as consumers, which will lay the grounds and generate the skills for innovation.

Why study the middle class as a relevant phenomenon to strategic marketing?

At the turn of the $19^{\text {th }}$ century, the rise of the American middle class led to the development of a mass market for many products (Strasser 1989). In turn, over the course of the $20^{\text {th }}$ century this process stimulated the development of the discipline of marketing. The rise of the new middle classes in emerging markets is not only a quantitative phenomenon, but can probably be viewed as the engine, along with the advent of new technologies, stimulating the formulation of new marketing models, new categories and new conceptual approaches for business in ever-broadening markets.

\section{References}

Banerjee A.V., Duflo E. (2008). What is middle class about the middle classes around the world?. Journal of Economic Perspectives, 22(2): 3-28, doi: 10.1257/jep.22.2.3.

Blumin S.M. (1989). The emergence of the middle class. Social experiences in the American cities 1760-1900. Cambridge: Cambridge University Press.

Carmichael M. (2011). Marketing myth: the vanishing middle class. Advertising Age, October 17, www.adage.com.

Coleman R.P. (1983). The continuing significance of social class to marketing. Journal of Consumer Research, 10, 3: 265-280, doi: 10.1086/208966.

Hong L. (2014). Marketing to China's middle class. China Business Review, January 6, www.chinabusinessreview.com.

Khanna T., Palepu K.G., Sinha J. (2005). Strategies that fit emerging markets. Harvard Business Review, June, 86, 6: 63-76.

Kharas H. (2010). The emerging middle class in developing countries. OECD Development Centre, Working Paper, 285: 1-61.

Mukherjee A., Satija D. (2012). The consumption pattern of the rising middle class in India. November 25, www.boaoreview.com

Prahalad C.K. (2012). Bottom of the pyramid as a source of breakthrough innovations. Journal of Product Innovation Management, 29, 1: 6-12, doi: 10.1111/j.1540-5885.2011.00874.x.

Reich R. (2011). The limping middle class. New York Times. September 3, www.nytimes.com.

Strasser S. (1989). Satisfaction guaranteed. The making of the American mass market. New York: Pantheon Books. 